Прилози, Одд. мат. тех. науки, МАНУ, XXVII-XXVIII, 1-2 (2006-2007), стр. 17-29

Contributions, Sec. Math. Tech. Sci., MANU, XXVII-XXVIII, 1-2 (2006-2007), pp. 17-29

ISSN $0351-3246$

UDC: $547.458 .2: 543.42$

\title{
INFRARED SPECTRA OF THIOSACCHARINATES OF CADMIUM AND LEAD COMPARISON WITH THE ANALOGOUS METAL SACCHARINATES
}

\author{
Gligor Jovanovski, Adnan Kahil, Orhideja Grupče
}

\begin{abstract}
A b s t r a c t: The Fourier transform (FT) infrared spectra of thiosaccharinates of cadmium and lead in the 4000-400 $\mathrm{cm}^{-1}$ region were studied. Although the observed resemblance between the spectra recorded in $\mathrm{KBr}$ pellets suggests a possible similarity between their structures as well, the powder X-ray diagrams show that these two compounds are not isomorphous. The presence of broad and intense bands in the region of the $\mathrm{HOH}$ stretchings shows that thiosaccharinate of cadmium is a crystalline hydrate and the spectral picture in the region of the O-D stretchings of the isotopically isolated HOD molecules in the partially deuterated analogue indicates that present in its structure are at least two types of crystallographically different water molecules involved in the formation of weak hydrogen bonds. The room temperature (RT) spectrum of lead thiosaccharinate in the region of the $v(\mathrm{HOH})$ modes differs significantly from the spectrum recorded at the boiling temperature of liquid nitrogen (LNT), which may perhaps be interpreted as an indication that a phase transition is taking place on lowering the temperature. The spectrum of lead thiosaccharinate was recorded in a Nujol mull as well. While the $\mathrm{KBr}$ and Nujol spectra are essentially identical in the region below $1600 \mathrm{~cm}^{-1}$, no bands are observed in the $\mathrm{HOH}$ stretching region of the mull spectra. In fact, it was shown that the appearance of the spectra of lead thiosaccharinates depends on the emulsion preparation rate. A comparison of the spectral characteristics of the thiosaccharinates of cadmium and lead with those of the corresponding saccharinates (their crystal structures are known) was made, special attention being paid to the analysis of the $\mathrm{SO}_{2}$ stretching region in the saccharinate and thiosaccharinate compounds.
\end{abstract}

Key words: cadmium; lead; thiosaccharinates; saccharinates; IR spectra 


\section{INTRODUCTION}

Compared with the lasting interest in the investigation of the potentially carcinogenic saccharin and its metal compounds resulting, in the last two decades, in an accumulation of a large body of published data on the structural and spectral characteristics of this class of compounds, much less has been done in the case of thioanalogue, thiosaccharin, and its compounds. So far, the structural characteristics of thiosaccharin and its compounds with various metals ( $\mathrm{Na}, \mathrm{K}, \mathrm{Mg}, \mathrm{Mn}, \mathrm{Co}, \mathrm{Ni}, \mathrm{Cu}, \mathrm{Zn}, \mathrm{Cd}, \mathrm{Pb}, \mathrm{Hg}$ ) have been studied using infrared spectroscopy and X-ray diffraction [1-7]. As an addition to these studies, the results of the investigation of the Fourier transform infrared (FTIR) spectra of the thiosaccharinates of cadmium and lead and their comparison with the spectra of the corresponding saccharinate analogues are given in the present paper.

\section{EXPERIMENTAL}

The thiosaccharinates of cadmium and lead were synthesized mixing aqueous solutions of $\mathrm{CdCl}_{2} \cdot 2 \mathrm{H}_{2} \mathrm{O}$ or $\mathrm{Pb}\left(\mathrm{NO}_{3}\right)_{2}$ with sodium thiosaccharinate. The obtained crystals of the formed salts were then filtered, washed with distilled water and ethanol and dried in a vacuum desiccator. The corresponding saccharinates were prepared analogously, only using sodium saccharinate instead of sodium thiosaccharinate. The infrared spectra were recorded on a Fourier transform interferometer Perkin-Elmer System 2000 in the $4000-370 \mathrm{~cm}^{-1}$ region applying the methods of the pressed $\mathrm{KBr}$ pellets and Nujol mulls. A lowtemperature cell $\mathrm{P} / \mathrm{N} 21525$ equipped with $\mathrm{KBr}$ windows was used for recording the infrared spectra at the boiling temperature of liquid nitrogen (LNT). The powder X-ray diagrams were recorded on a JDX-75 diffractometer using $\mathrm{Cu}-\mathrm{K} \alpha$ radiation.

\section{RESULTS AND DISCUSSION}

The Fourier transform infrared spectra of the thiosaccharinates of cadmium and lead recorded at room temperature (RT) and LNT are shown in Fig. 1 and Fig. 2 respectively, and those of the saccharinates of $\mathrm{Cd}$ and $\mathrm{Pb}$ are shown in Fig. 3 and Fig. 4 respectively. A pronounced difference between the spectra of the saccharinates and the corresponding thiosaccharinates is apparent, both 
in the region of the $\mathrm{HOH}$ stretching modes and in the spectrum in general. As can be seen, the substitution of the oxygen atom in the five-membered ring of saccharin with a sulfur atom dramatically changes the overall appearance of the IR spectra, due to the more extensive coupling of the vibrational modes in the case of thiosaccharin. On the other hand, the infrared spectra of the thiosaccharinates of cadmium and lead recorded in $\mathrm{KBr}$ pellets are very similar (Fig. 1 and Fig. 2) although it is perhaps worth mentioning that the room-temperature spectrum of $\mathrm{Pb}$-thiosaccharinate in the region of the $v(\mathrm{HOH})$ modes differs from the corresponding LNT spectrum (see Fig. 5). The presence of the broad and rather intense bands in the region of the stretching $\mathrm{HOH}$ vibrations of the infrared spectra of the two compounds under investigation may be taken as an indication that these two thiosaccharinates are hydrates. As discussed below, such a conclusion is certainly applicable to the thiosaccharinate of cadmium under all experimental conditions encountered in this study, whereas the corresponding lead salt may or may not be a crystalline hydrate as well.

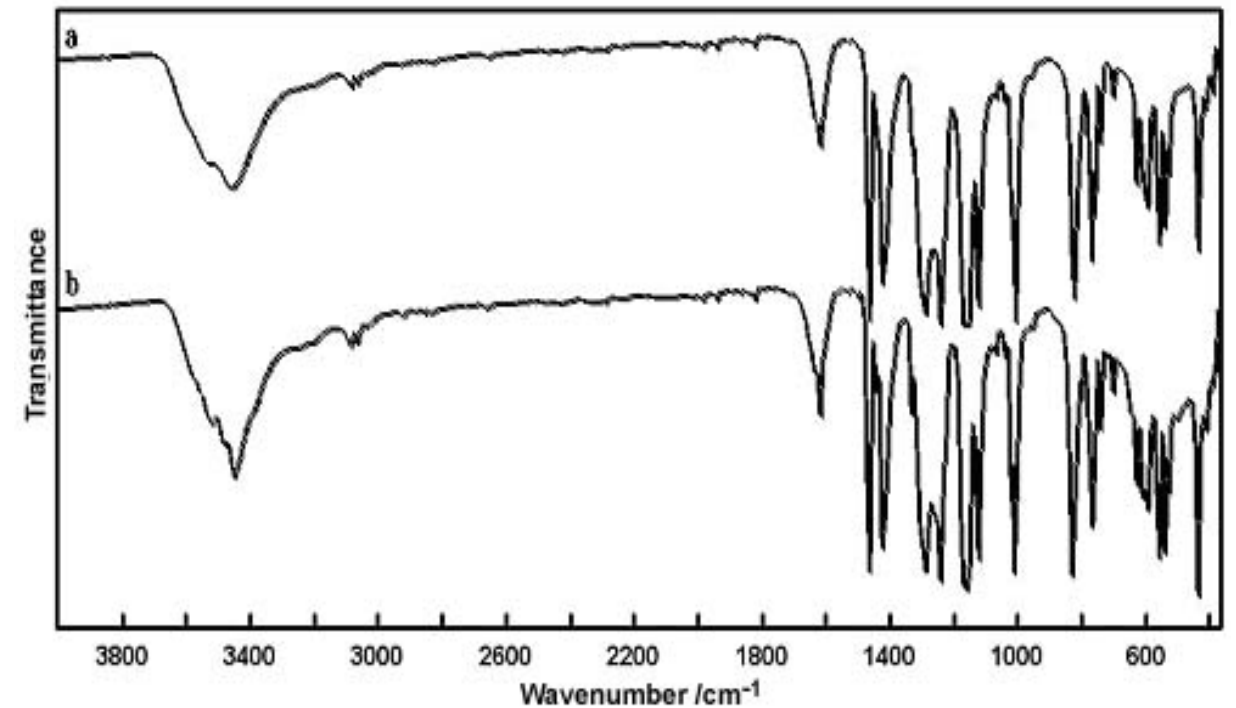

Fig. 1. Fourier transform infrared spectra of the Cd-thiosaccharinate hydrate recorded in a $\mathrm{KBr}$ pellet, at RT (a) and LNT (b)

Прилози, Одд. мат. тех. науки, XXVII-XXVIII, 1-2 (2006-2007), стр. 17-29 


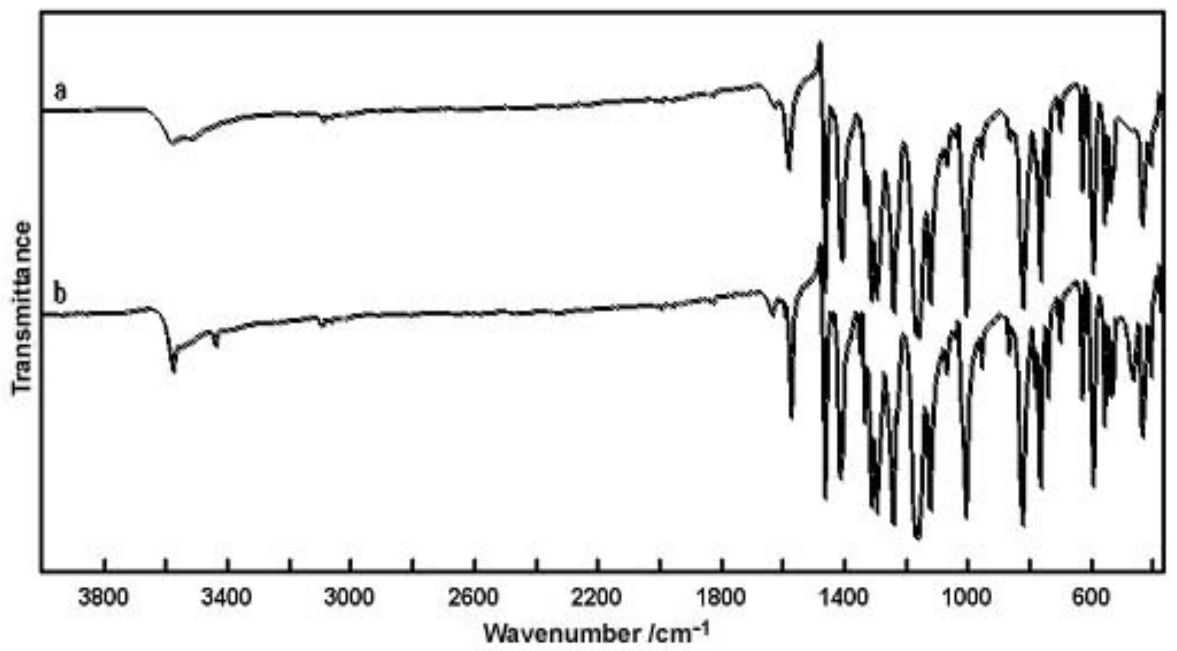

Fig. 2. Fourier transform infrared spectra of the $\mathrm{Pb}$-thiosaccharinate hydrate, recorded in a $\mathrm{KBr}$ pellet, at RT (a) and LNT (b)

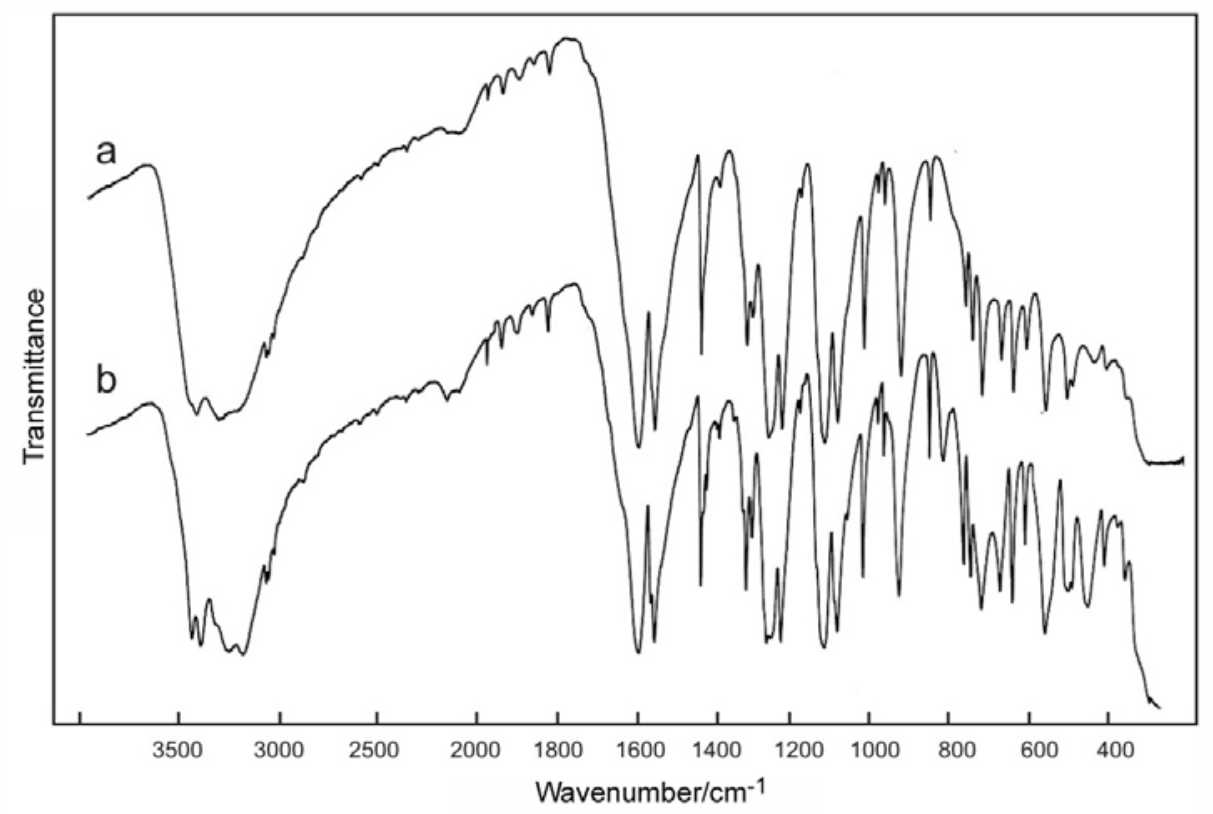

Fig. 3. Infrared spectra of the $\left[\mathrm{Cd}(\mathrm{sac})_{2}\left(\mathrm{H}_{2} \mathrm{O}\right)_{4}\right] \cdot 2 \mathrm{H}_{2} \mathrm{O}$ recorded at RT (a) at LNT (b). Hereafter sac is an abbreviation for the saccharinato ligand/ion 


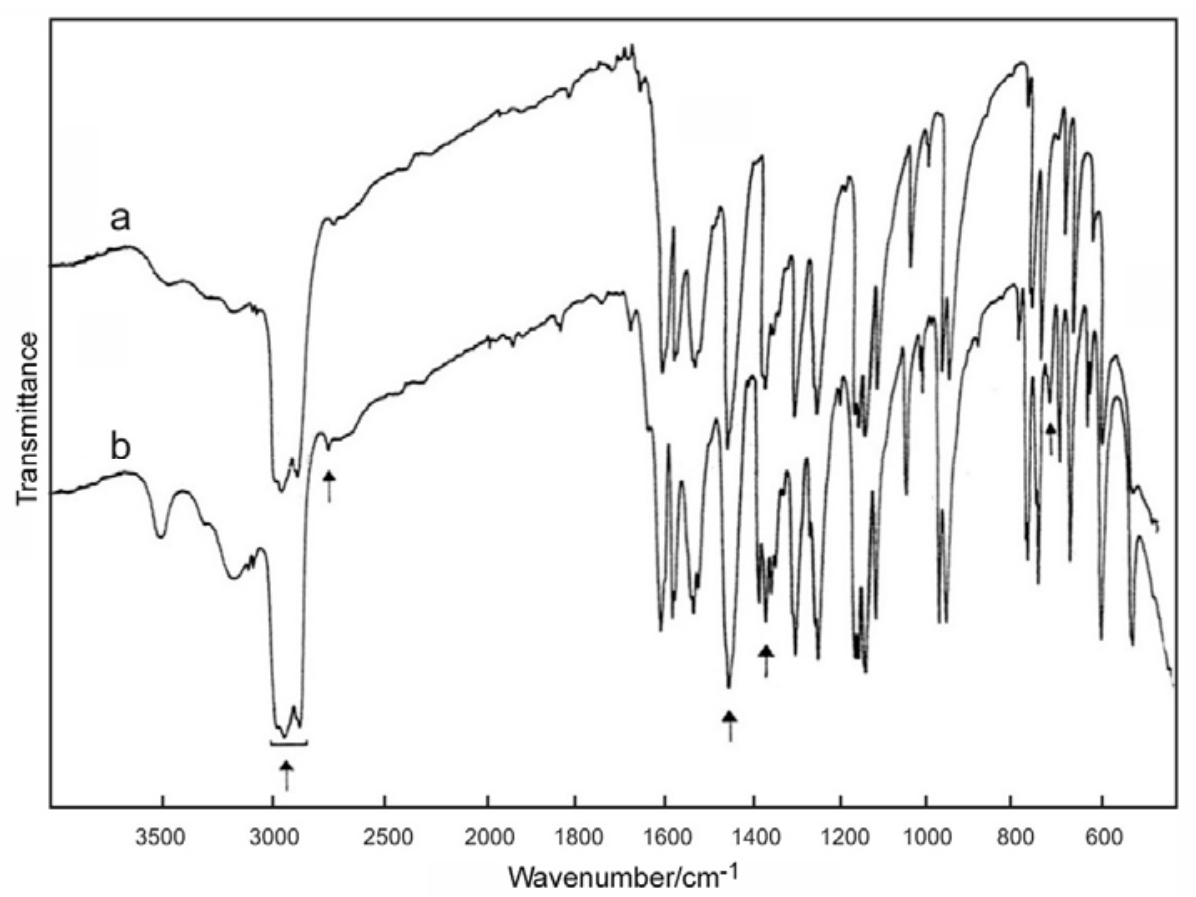

Fig. 4. Infrared spectra of the $\mathrm{Pb}(\mathrm{sac})_{2} \cdot \mathrm{H}_{2} \mathrm{O}$ recorded at $\mathrm{RT}(\mathrm{a})$ and $\mathrm{LNT}(\mathrm{b})$. The Nujol bands are denoted by arrows

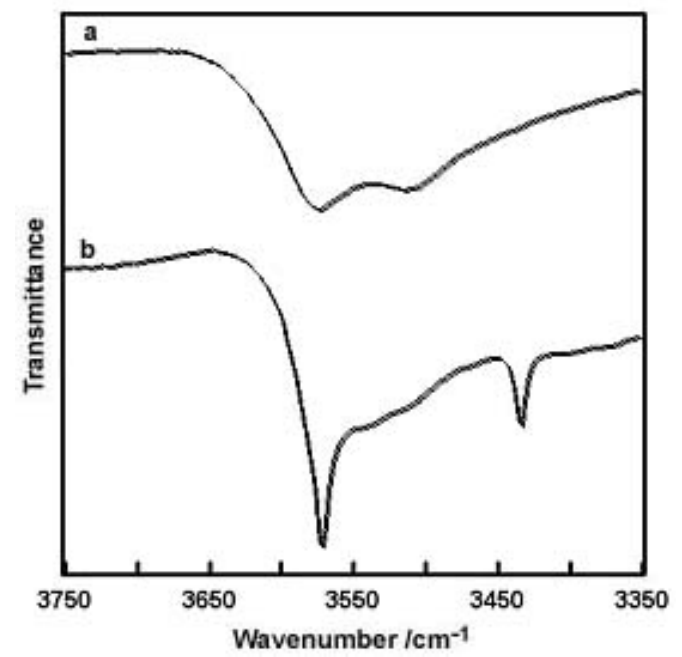

Fig. 5. Fourier transform infrared spectra of the hydrated $\mathrm{Pb}$-thiosaccharinate at room (a) and low temperature (b) in the region of the $v(\mathrm{OH})$ vibrations

Прилози, Одд. мат. тех. науки, XXVII-XXVIII, 1-2 (2006-2007), стр. 17-29 
The appearance of four bands in the infrared spectrum of the partially deuterated analogue of cadmium thiosaccharinate in the region of the OD stretchings due to the presence of the isotopically isolated HOD molecules (Fig. 6) indicates that at least two types of crystallographically independent water molecules are present in the structure of this compound, being included in formation of weak hydrogen bonds. This is confirmed by the appearance of at least two bands in the region of the $\mathrm{HOH}$ deformations around $1600 \mathrm{~cm}^{-1}$ (Fig. 1).

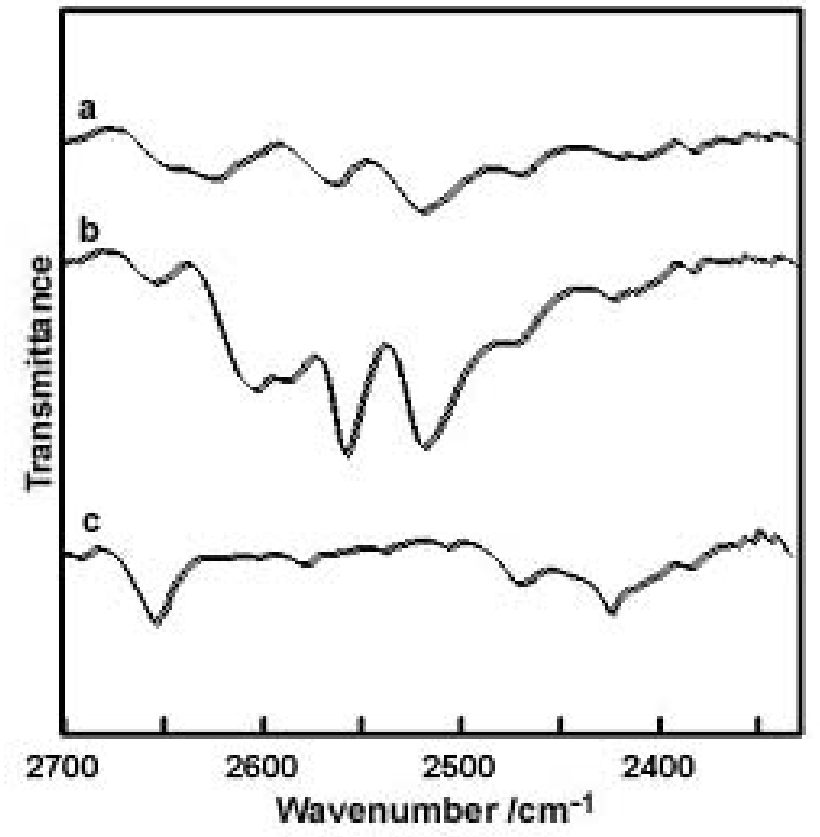

Fig. 6. Fourier transform infrared spectra of low deuterated Cd-thiosaccharinate recorded at RT (a) and LNT (b) and Cd-thiosaccharinate recorded at LNT (c) in the region of the $v(O D)$ modes

As mentioned above, the situation with the thiosaccharinate of lead is more complicated. Namely, the structural similarities between the thiosaccharinates of cadmium and lead suggested by the appearance of the infrared spectra recorded in $\mathrm{KBr}$ were not proven by the X-ray diagrams of their powdered samples, which clearly show that these two compounds are not isomorphous (see Fig. 7). 


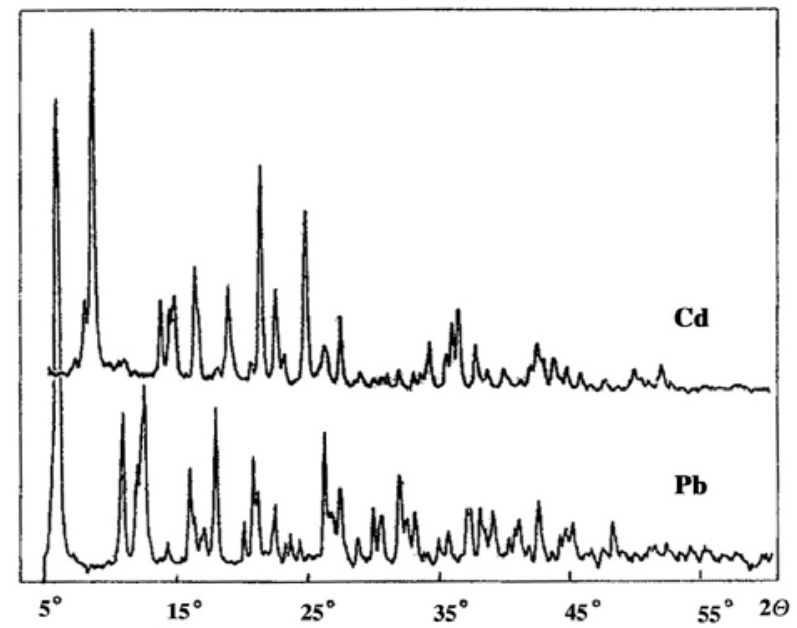

Fig. 7. X-ray powder patterns of the thiosaccharinates of cadmium and lead

To further check the reasons behind the apparent inconsistence between the infrared and $\mathrm{X}$-ray results, the infrared spectra of $\mathrm{Pb}$-thiosaccharinate were recorded in Nujol mulls as well as in $\mathrm{KBr}$. As seen in Fig. 8, the spectra recorded by both techniques are essentially identical except the $\mathrm{HOH}$ spectral region, where the bands due to the $v(\mathrm{HOH})$ modes would be expected. In fact, no bands were observed in the spectrum of the Nujol emulsion of Pb-thiosaccharinate. Later on it was shown that the spectral picture in the above-mentioned region depends on the rate of the emulsion preparation, bands appearing and becoming more intense as the rate of the mull preparation is increased (see Fig. 9).

In the spectrum of the partially deuterated analogue of $\left[\mathrm{Cd}(\mathrm{sac})_{2}\left(\mathrm{H}_{2} \mathrm{O}\right)_{4}\right] \cdot 2 \mathrm{H}_{2} \mathrm{O}$, five bands appear due to the presence of the isotopically isolated HOD molecules in the region of $\mathrm{O}-\mathrm{D}$ stretching vibrations [11] (Fig. 10). This is consistent with the existence of three types of crystallographically different water molecules and five $\mathrm{O}_{\mathrm{w}} \cdots \mathrm{A}$ distances in the structure of the Cd compound $[8,9]$. The presence, however, of only one type of crystallographically different water molecule (with two different $\mathrm{O}-\mathrm{H}$ distances) in the structure of $\mathrm{Pb}(\mathrm{sac})_{2} \cdot \mathrm{H}_{2} \mathrm{O}$ [10] agrees well with the observation of two bands in the region of the $v(\mathrm{OD})$ vibrations of the isotopically isolated HOD molecules [12] (Fig. 10). Due to the insolubility in water of lead thiosaccharinate, a comparative study of the infrared spectrum of a partially deuterated analogue in the region of the OD stretching vibrations of the isotopically isolated HOD molecules was not possible. 


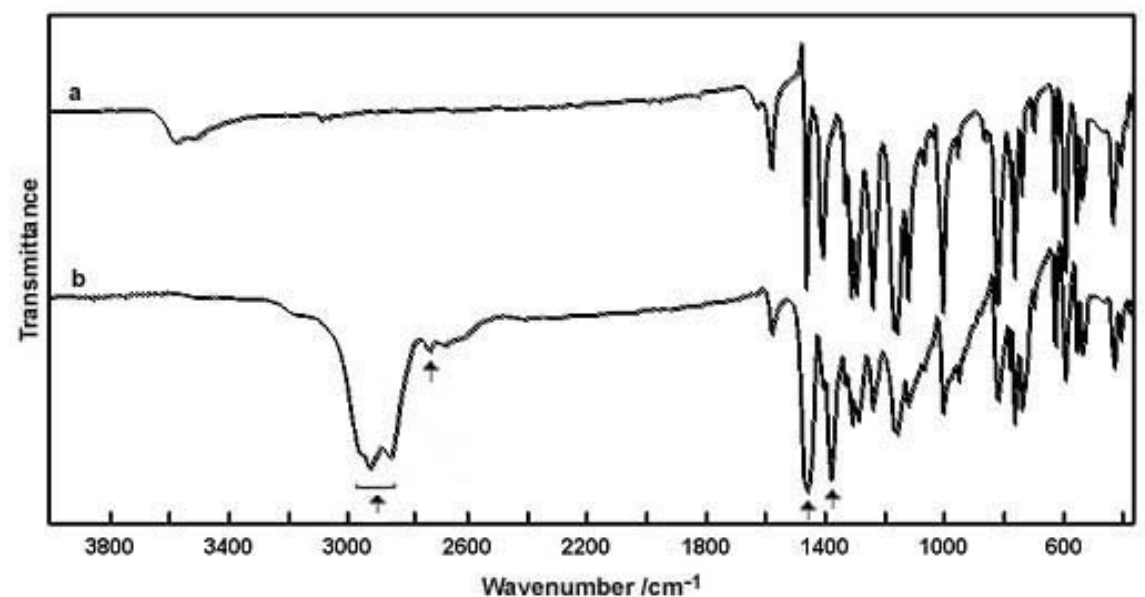

Fig. 8. Fourier transform infrared spectra of $\mathrm{Pb}$-thiosaccharinate recorded at $\mathrm{RT}$ in $\mathrm{KBr}$

(a) and in the Nujol emulsion (b); the Nujol bands are denoted by arrows

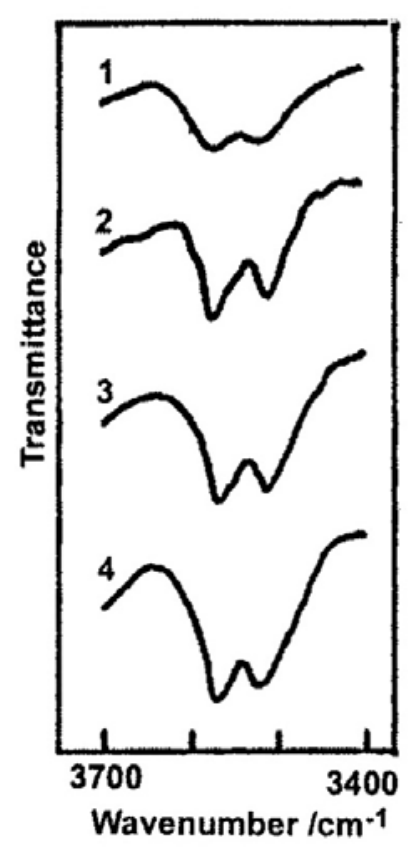

Fig. 9. Dependence of the $v(\mathrm{HOH})$ band intensity in the spectrum of lead thiosaccharinate on the emulsion preparation rate increasing (going from 1 to 4 ) 


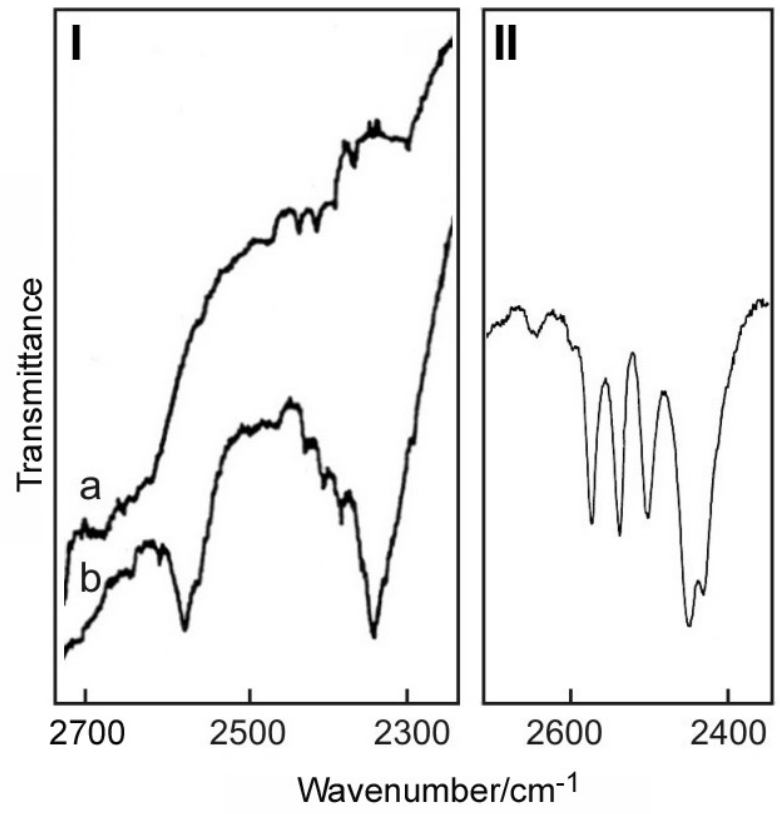

Fig. 10. Fourier transform infrared spectra of the $\mathrm{Pb}(\mathrm{sac})_{2} \cdot \mathrm{H}_{2} \mathrm{O}(\mathrm{Ia}), \mathrm{Pb}(\mathrm{sac})_{2} \cdot \mathrm{HDO}$ (Ib) and $\left.\left[\mathrm{Cd}(\mathrm{sac})_{2}(\mathrm{HD})_{2} \mathrm{O}\right)_{4}\right] \cdot 2(\mathrm{HD})_{2} \mathrm{O}[\mathrm{II}]$ recorded at $\mathrm{LNT}$ in the region of the $\mathrm{v}(\mathrm{OD})$ vibrations of the isotopically isolated HOD molecules

Special attention in this work was focused on the region of the $\mathrm{SO}_{2}$ stretchings. Since the $\mathrm{SO}_{2}$ vibrations are considered as good group vibrations (being usually manifested as the strongest bands in the spectrum), they are studied in detail for a number of various metal saccharinates (see [13] and references therein). As was shown by the IR spectral analysis and confirmed by the $a b$ initio force field treatment $[13,14]$, the common feature for both types of compounds (metal saccharinates and metal thiosaccharinates) is that $v_{\mathrm{as}}\left(\mathrm{SO}_{2}\right)$ vibrations appear at lower frequency than the corresponding mode in saccharin/thiosaccharin themselves. On the other hand, the $v_{\mathrm{s}}\left(\mathrm{SO}_{2}\right)$ mode shifts to lower frequencies only in the infrared spectra of the saccharinate compounds whereas the frequency of this mode in the infrared spectra of the metal thiosacharinates is either higher than in the case of tiosaccharin itself or remains unchanged (Table 1). The mixed character of the $v_{\mathrm{s}}\left(\mathrm{SO}_{2}\right)$ mode in thiosaccharin is, most probably, the main reason for this peculiarity [14]. 
Ta ble 1

Structural and spectroscopic data concerning the $\mathrm{SO}_{2}$ groups in saccharin and thiosaccharin and the corresponding compounds of cadmium and lead

\begin{tabular}{lcccc}
\hline \hline Compound & $\mathrm{R}(\mathrm{S}-\mathrm{O}) / \mathrm{pm}$ & $<(\mathrm{O}-\mathrm{S}-\mathrm{O}) /^{\circ}$ & $v_{\mathrm{as}}\left(\mathrm{SO}_{2}\right) / \mathrm{cm}^{-1}$ & $v_{\mathrm{s}}\left(\mathrm{SO}_{2}\right) / \mathrm{cm}^{-1}$ \\
\hline Saccharin $[13,15]$ & 142.9 & 117.7 & 1335 & 1180 \\
& 140.9 & & & \\
$\mathrm{Cd}(\mathrm{sac})_{2}\left[\left(\mathrm{H}_{2} \mathrm{O}\right)_{4}\right] \cdot 2 \mathrm{H}_{2} \mathrm{O}[8,9,13]$ & 144.5 & 116.1 & 1288 & 1155 \\
& 143.7 & & & \\
$\mathrm{~Pb}(\mathrm{sac})_{2} \cdot \mathrm{H}_{2} \mathrm{O}[10,13]$ & 143.9 & 120.4 & 1308 & 1167 \\
& 143.3 & 109.5 & 1255 & 1142 \\
& 146.3 & & & \\
Thiosaccharin $[1,5]$ & 142.9 & & & \\
& 143.1 & 117.5 & 1320 & 1155 \\
$\mathrm{Cd}(\text { thiosac })_{2} \cdot \mathrm{xH}_{2} \mathrm{O}^{*}$ & 142.5 & & & \\
$\mathrm{~Pb}$ (thiosac $)_{2} \cdot \mathrm{xH}_{2} \mathrm{O}$ & & & 1286 & 1155 \\
\hline \hline
\end{tabular}

*Thiosac is abbreviation for the thiosaccharinate ligand/ion.

As has already been shown [13], the geometrical characteristics of the $\mathrm{SO}_{2}$ group, especially the $\mathrm{O}-\mathrm{S}-\mathrm{O}$ angle, affect the frequencies of the $\mathrm{SO}_{2}$ stretches. Thus, in the case of $\mathrm{Pb}(\mathrm{sac})_{2} \cdot \mathrm{H}_{2} \mathrm{O}[10,13]$ two pairs of bands appear (Fig. 4 and Table 1) due to the two rather different $\mathrm{O}-\mathrm{S}-\mathrm{O}$ angles in the crystallographically different $\mathrm{SO}_{2}$ groups present in the structure. On the other hand, in the case of $\left.\mathrm{Cd}(\mathrm{sac})_{2}\left(\mathrm{H}_{2} \mathrm{O}\right)_{4}\right] \cdot 2 \mathrm{H}_{2} \mathrm{O}$ where a single type of $\mathrm{SO}_{2}$ groups exists, only one pair of $\mathrm{SO}_{2}$ stretching bands appears $[8,13]$. In the IR spectra of the studied thiosaccharinate compounds single pairs of $\mathrm{SO}_{2}$ stretches also appear, thus suggesting the presence of only one type of crystallographically different $\mathrm{SO}_{2}$ group in each of the two compounds as well. The strong bands at $1155 \mathrm{~cm}^{-1}$ (cadmium) and $1160 \mathrm{~cm}^{-1}$ (lead) are assigned to the $\mathrm{v}_{\mathrm{s}}\left(\mathrm{SO}_{2}\right)$ mode, whereas the intense bands at $1286 \mathrm{~cm}^{-1}$ (cadmium) and $1290 \mathrm{~cm}^{-1}$ (lead) are attributed to the $v_{\text {as }}\left(\mathrm{SO}_{2}\right)$ mode (see Fig. 1 and Fig. 2 and Table 1). Although these two thiosaccharinate compounds exhibit very similar behavior in the region of the $\mathrm{SO}_{2}$ modes, this cannot be used as a definitive basis for far-reaching conclusions about the type of metal-to-ligand bonding, since various factors affect the frequency of the of $\mathrm{SO}_{2}$ stretches [13]. 


\section{CONCLUSIONS}

The study has shown that:

- The thiosaccharinate of cadmium is a crystalline hydrate. At least two crystallographically different water molecules are present in its structure. The true nature of the corresponding lead salt is open to discussion.

- In the $v(\mathrm{HOH})$ spectral region differences exist between the infrared spectra of lead thiosaccharinate recorded by the methods of pressed $\mathrm{KBr}$ pellets and those obtained from Nujol mulls, the intensity of the bands in the latter case being dependent on the emulsion preparation rate.

- Significant differences between the IR spectra of the saccharinates of cadmium and lead, on the one hand, and the corresponding thiosaccharinate analogues, on the other hand, are observed. They are apparently mainly due to the more expressed coupling of the vibrational modes in the case of the thiosaccharinate compounds.

- The IR spectral picture in the region of the $v\left(\mathrm{SO}_{2}\right)$ stretchings suggests that only one type of $\mathrm{SO}_{2}$ group is present in the structures of the studied compounds, implying the existence of a single type of thiosaccharinate ligands/ions in their structures.

Acknowledgement. The financial support from the Ministry of Education and Science of the Republic of Macedonia is gratefully acknowledged.

\section{REFERENCES}

[1] O. Grupče, M. Penavić, G. Jovanovski, J. Chem. Crystallogr., 24, 581 (1994).

[2] M. Penavić., G. Jovanovski, O. Grupče, Acta Crystallogr., C46 , 2341 (1990).

[3] M. Penavić, O. Grupče, G. Jovanovski, Acta Crystallogr., C47, 1821 (1991).

[4] O. Grupče, G. Jovanovski, B. Šoptrajanov, J. Mol. Struct., 267, 197 (1992).

[5] O. Grupče, G. Jovanovski, B. Šoptrajanov, J. Mol. Struct., 293, 113 (1993).

[6] O. Grupče, G. Jovanovski, Anal. Labor., 7, 9 (1998).

Прилози, Одд. мат. тех. науки, XXVII-XXVIII, 1-2 (2006-2007), стр. 17-29 
[7] A. Kahil, G. Jovanovski, O. Grupče, Bull. Chem. Technol. Macedonia, 19, 9 (2000).

[8] B. Kamenar, G. Jovanovski, Cryst. Struct. Comm., 11, 257 (1982).

[9] S. Z. Haider, K. M. A. Malik, S. Das, Acta Crystallogr., C40, 1147 (1984).

[10] G. Jovanovski, A. Hergold-Brundić, B. Kamenar, Acta Crystallogr., C44, 63 (1988).

[11] G. Jovanovski, B. Šoptrajanov, J. Mol. Struct., 143, 159 (1986).

[12] S. Tančeva, G. Jovanovski. B. Šoptrajanov, Spectrosc. Lett., 25, 927 (1992).

[13] G. Jovanovski, S. Tančeva. B. Šoptrajanov, Spectrosc. Lett., 28, 1095 (1995).

[14] Y. I. Binev, C. T. Petkov, Lj. Pejov, Spectrochim. Acta A59, 1949 (2000).

[15] Y. Okaya, Acta Crustallogr., B25, 2257 (1969).

$$
\text { Р е з и м е }
$$

\section{ИНФРАЦРВЕНИ СПЕКТРИ НА ТИОСАХАРИНАТИТЕ НА КАДМИУМ И ОЛОВО СПОРЕДБА СО АНАЛОГНИТЕ МЕТАЛНИ САХАРИНАТИ}

Изучувани се $Ф$ Т инфрацрвени спектри на тиосахаринатите на кадмиум и олово во подрачјето од 4000 до $400 \mathrm{~cm}^{-1}$. И покрај тоа што набљудуваната сличност меѓу спектрите укажува на можна сличност и на нивните структури, рендгенограмите на спрашените обрасци покажуваат дека овие две соединенија не се изоморфни помеѓу себе. Присуството на широки и интензивни ленти во подрачјето на валентните $\mathrm{HOH} \mathrm{вибрации} \mathrm{во} \mathrm{спектрите} \mathrm{снимени} \mathrm{во} \mathrm{пресувани} \mathrm{таблети} \mathrm{од} \mathrm{KBr}$ како да укажува дека тиосахаринатите на кадмиум и олово се кристалохидрати. Изгледот на спектарот на кадмиум тиосахаринатот во подрачјето на валентните OD вибрации кои потекнуваат од присуството на изотопски изолирани HOD молекули во парцијално деутерираниот аналог укажува дека во структурата на ова соединение постојат најмалку два типа на кристалографски независни молекули вода кои учествуваат во создавање на слаби водородни врски. Ваквиот наод покажува дека ова соединение е несомнено кристалохидрат. Од друга страна, повнимателната анализа на спектрите на соединението на оловото ја става под сомнение неговата вистинска природа. Имено, освен од таблетка од $\mathrm{KBr}$, инфрацрвениот спектар на олово тиосахаринатот беше снимен и од емулзија од Nujol. Макар што, глобално гледано, спектрите снимени со двете различни техники се чинат идентични, постојат јасни разлики во валентното HOH подрачје. Имено, во спектарот снимен во Nujol, во подрачјето на $v(\mathrm{OH})$ модовите појавувањето или непојавувањето на ленти и нивниот интензитет зависи од брзината на подготвување на емулзијата, со тоа што интензитетот на лентите расте со зголемување на брзината на подготвување на образецот за снимање. Освен тоа, спектралната слика во подрачјето на $v(\mathrm{HOH})$ модовите од инфрацрвениот спектар на олово тиосахаринатот снимен на собна температура е битно различна од онаа во спектарот добиен на температурата на вриење на течен азот така што е можно при снижување на температурата евентуално да доаѓ до фазна трансформација во која би биле вклучени молекулите од вода. Во секој случај, потребни се на- 
тамошни испитувања на ова соединение. Спектралните карактеристики на тиосахаринатите на кадмиум и олово се споредени со оние на соодветните сахаринати чии кристални структури се познати. Притоа, со цел да се добијат некои структурни сознанија за тиосахаринатните аналози, посебно внимание е посветено на валентните вибрации на $\mathrm{SO}_{2}$ групите во спектрите на сахаринатните и тиосахаринатните соединенија.

Клучни зборови: кадмиум; олово; тиосахаринати; сахаринати; инфрацрвени спектри

Adress:

Gligor Jovanovski

Institute of Chemistry, Faculty of Natural Sciences and Mathematics, "SS. Cyril and Methodius" University, Skopje,

P. O. Box 162, MK-1001 Skopje, Republic of Macedonia

gligor@pmf.ukim.edu.mk

\section{Adnan Kahil}

Institute of Chemistry, Faculty of Natural Sciences and Mathematics,

"SS. Cyril and Methodius" University, Skopje,

P. O. Box 162, MK-1001 Skopje, Republic of Macedonia

Orhideja Grupče

Institute of Chemistry, Faculty of Natural Sciences and Mathematics, "SS. Cyril and Methodius" University, Skopje,

P. O. Box 162, MK-1001 Skopje, Republic of Macedonia

orhideja@iunona.pmf.ukim.edu.mk

Received: 28. II 2005

Accepted: 4. III 2005

Прилози, Одд. мат. тех. науки, XXVII-XXVIII, 1-2 (2006-2007), стр. 17-29 